\section{SCORECARD}

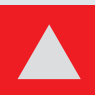

Stem cells on the ISS

NASA's decision to

include privately funded

research on the International Space Station from 2011 could see stem cells, and other biomed products, going into space.

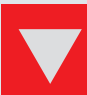

Everything else at NASA With charges of drunken astronauts and lost and sabotaged equipment, NASA has more pressing concerns to address before turning to next decade's bioethics issues.

\section{ON THE RECORD}

'The toes date from between 1000 and 600 $B C$, so if we can prove they were functional we will have pushed back prosthetic medicine by as much as 700 years."

Biomedical egyptologist Jacky Finch of the University of Manchester, UK, who is studying ancient Egyptian big toes, made of wood and leather, from museums in Cairo and London. She's looking for people who have lost their right big toe and wouldn't mind helping to test out a modern replica.

\section{OVERHYPED}

Oscar, the cat of doom If you believe the news, the cat who can "predict death" at a Rhode Island nursing home has "left doctors baffled". And so, abetted by the New England Journal of Medicine, where the story first appeared, summer's silly season for'science' stories begins.

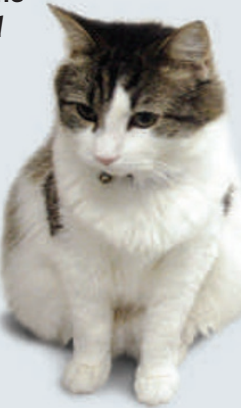

\section{ZOO NEWS}

\section{Tentacle treasure}

An octopus found with a porcelain plate stuck to its suckers has led archaeologists to a hoard of ancient pottery shipwrecked in a twelfth-century boat off the coast of South Korea.

Sources: The Scientist, news@nature.com, EurekAlert, BBC N. Engl. J. Med.

\title{
Russia at forefront of Arctic land-grab
}

Marine scientists are voicing concerns that their research may be jeopardized by the international scrum to claim the Arctic seabed.

Last week, Russia highlighted its claims to a vast chunk by sending a mission to drop a titanium capsule with a Russian flag on the seabed underneath the North Pole. Canada, Norway, the United States and Denmark (on behalf of Greenland) are also preparing claims.

The 1982 United Nations Convention on the Law of the Sea (UNCLOS) allows states an economic zone that extends 200 nautical miles from their coastline. To increase this, countries must prove to the United Nations Commission on the Limits of the Continental Shelf that their physical

"There could be very little free space left in the Arctic Ocean." in geological and polar research. "Access is already a problem," says Mead Treadwell, chair of the US Arctic Research Commission. "We've looked at maps which show there could be very little free space left in the Arctic Ocean."

Anders Karlqvist, director of the Swedish Polar Research Secretariat, agrees. "It will probably mean research will be more regulated in terms of getting permission and documentation that goes through various organizations in the countries concerned. And if the political climate changes it may lead to research restrictions."

But the contest is providing plenty of work for some marine geologists in the run-up to many countries' deadline for submissions of May 2009. "I've never continental margin extends farther than this. If Moscow can prove that the structure of the continental shelf under the ocean is geologically similar to that of Russian land, it may be able to extend its territory. The Lomonosov Ridge, which it sees as a continental extension, is key to its claims. Russia hopes to claim 1.2 million square kilometres and, with it, the rights to copious mineral and fossil-fuel reserves. Estimates vary, but some suggest that the Arctic contains as much as $25 \%$ of the world's oil reserves.

A successful claim would not allow nations to control water above the seabed, but anyone doing research on the ocean floor would need permission, which worries some involved worked so hard on strategic policy as now," says at the United Kingdom's National Oceanography Centre in Southampton.

To prove their claims, countries need to collect bathymetric data that accurately describe the underwater lie of the land and seismic data on the structure of the sea floor. These data can be used to determine where the continental shelf off a country's coast falls away in a 'continental slope' and how far sediments derived from the land extend out beyond the foot of that slope. The sea floor can be claimed if it is sedimentary rock at least $1 \%$ as thick as its distance from the foot of the continental slope. These measureLindsay Parson, who leads the UNCLOS Group

\section{New life for nuclear warheads}

The US Department of Energy facility will help to dispose of is starting construction of a dangerous weapons material controversial facility to recycle safely. But sceptics, including nuclear warheads.

On 1 August, work finally began on a US $\$ 4.8$ billion mixed-oxide fuel-fabrication facility at the Savannah River Site in South Carolina. The plant will convert surplus, weapons-grade plutonium into fuel for sale to commercial power reactors in North and South Carolina.

Supporters claim that the agreement with Russia. The technique blends plutonium with uranium so that it can be burned in conventional light-water reactors. Dozens of European reactors run on mixed-oxide fuel made from old commercial fuel, according to Matthew Bunn, a nonproliferation expert at Harvard University in Cambridge, Massachusetts.

The US plant design is actually a smaller version of the commercial French 


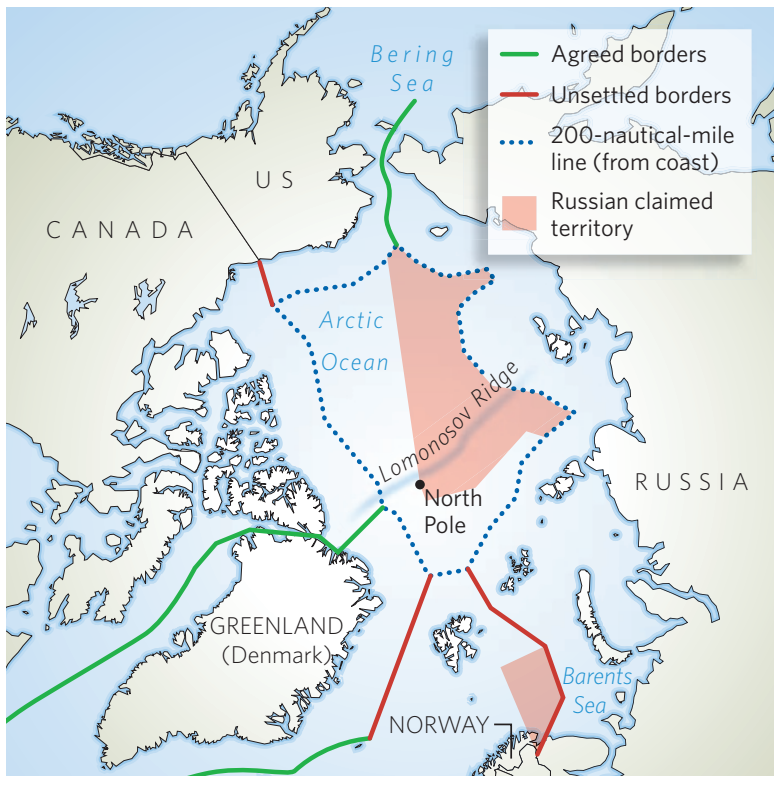

ments require input from geologists and oceanographic experts. If there is no sedimentary rock, a country is only entitled to claim an additional 60 nautical miles out.

Satellite sensing is useless for imaging the seabed because of the overlying water, and Arctic research is further complicated by sea ice. Even when data can be gleaned by research ships, interpretation is tricky. "In many circumstances around the world when the ocean basins form and these ridges get stranded out in the middle of the ocean, it's not easy to say whether there's a greater attachment at one end of the ridge or the other," notes Parson.

In 2001, Russia became the first country to make a submission to the United Nations. It was told to supply more information, in particular about the Lomonosov Ridge, which runs under the Arctic Ocean between Russia and Canada. Russia claims this ridge is an extension of its Siberian shelf, but this is hotly contested by Canada and others. On 29 July, Russia sent two mini-submarines, Mir-1 and Mir-2 to a depth of 1.3 kilometres in the first-ever Arctic test dives to gather data to boost its claims. The subs are part of an expedition to the North Pole involving a 100-strong team of Russian scientists aboard the Academician Fedorov, the flagship vessel of the Federal Service for Hydrometeorology and Environment Monitoring.

Meanwhile, Canadian Prime Minister Stephen Harper has announced plans to spend around Can $\$ 7$ billion (US $\$ 6.5$ billion) on up to eight new reinforced Arctic patrol vessels. "Canada has a choice when it comes to defending our sovereignty in the Arctic; either we use it or we lose it," Harper said. "And make no mistake, this government intends to use it. Because Canada's Arctic is central to our identity as a northern nation. It is part of our history and it represents the tremendous potential of our future." Canada is claiming 1.75 million square kilometres of the Arctic seabed.

The Arctic is not the only contentious seabed. Countries around the world, including New Zealand, Brazil and Ireland, have already submitted claims to the United Nations. Parson is involved in the United Kingdom's four claims - one, which concerns the Bay of Biscay, will be submitted by the end of August.

Daniel Cressey
Melox reprocessing facility at Marcoule. Engineers have modified the design slightly to handle weaponized plutonium alloys, and they have reduced shielding because weapons-grade isotopes are less radioactive than spent commercial fuel.

The programme gained political momentum in part because Russia was planning to build a sister facility to convert an equal amount of its own plutonium surplus, according to Daryl Kimball, executive director of the Arms Control Association in Washington DC.
But the Russians have backed away from the plan in recent years, Kimball says.

The US plant has also been beset by policy reviews, a lengthy licensing process and congressional opposition. It is now more than a decade behind schedule, and construction costs have ballooned by nearly $400 \%$ since 2002.

Nevertheless, department officials stand by the programme. In addition to fulfilling their disarmament obligations, the plan will be cheaper than long-term storage, Secretary of Energy Samuel Bodman told Congress. Bunn disagrees, in part because the department will be storing other plutonium anyway. "The cost of having a few extra bunkers is actually very modest," he says.

Which side Congress will take remains to be seen. The Senate is proposing roughly $\$ 390$ million for construction in fiscal year 2008, but House appropriators want to give it just $\$ 168$ million. A final compromise is expected to be reached later this autumn. Geoff Brumfiel 